\title{
A CLASSROOM ACTION RESEARCH IN SMA MUHAMMADIYAH 7 MAKASSAR: THE EFFECT OF SIMULATION TECHNIQUE IN SPEAKING ACCURACY
}

\author{
Wongso Adi Saputra \\ English Education Department, Universitas Muhammadiyah Makassar \\ Wongso.adisaputra@unismuh.ac.id
}

\begin{abstract}
This research aimed to observe and know the improvement of students' speaking skill at the second grade Exact students of SMA Muhammadiyah 7 Makassar which amount 22 students, that covers in accuracy and fluency through Simulation Technique in Classroom Action Research (CAR). To know the students' improvement achievement, the researcher used Diagnostic test, test cycle II, and test cycle II. Before implementing test cycle I and cycle II, the researcher applied action to the students through two cycles, which covers four meetings for each cycle. Cycle I test result had showed the improvement in the students speaking skill in the comparison with the diagnostic test, that is 3.5 (3.4 for accuracy and 3.6 for fluency) in the diagnostic test but that improvement is still not complete the standard score which is 6.5, so that the researcher continued to apply cycle II. And in the test cycle II finally the students showed the improvement significantly which is 7 for accuracy. That result proved that Simulation Technique could improve the students' speaking skill at the second grade exact students of SMA Muhammadiyah 7 Makassar.
\end{abstract}

Keywords: Simulation, Technique, Speaking, Accuracy

\section{INTRODUCTION}

Speaking was the common way people communicate and consider being productive skill. For most people, speaking was the basic system of communication. By speaking with other, people were able to know what kinds of situation are in the world. Beside that some people identify someone's ability of English through their speaking performance. Riwindiasih, (2009:2) states that people must be able to speak English well because other people identify the English mastery with their speaking well. But in the reality most of the students in the school were still lack of skill in speaking. It's prooved by the diagnostic test that they got only 3.5 and it's very low than the expected score in the standard score 6.5 in the school where this research done. The students are lack in speaking because they didn't have any opportunity to enhance their speaking skill. Neither performed it in the class or outside the class. Furthermore, we knew that language is habitual. 
Language is not only taught and learnt but it's also used as habitual. The process of teaching and learning process in some schools is still lack of practice and train students to use English in speaking directly in the class. It is also known that the successful of the people communication depends on how often they use their communication socialy. In that case, we are supposed to be creative in developing their teaching learning process to create good atmosphere, improving the student's speaking skill, giving attention to the elements of speaking and making the English lesson more exciting. Considering the explanation before, researcher had responsibility to have teaching method in order to solve the problem faced by the students in learning English, especially speaking. There are various methods in teaching speaking. Such as Simulation Technique (ST).

Simulation is a situation in which a particular set of conditions is created artificially in order to study or experience something that could exist in a reality. The most common view of simulations is that they provide a way of creating a rich communicative environment (a present of reality) where the students actively become a part of some real-world system and function according to predetermined roles as members of that group. More important, however, is the notion that a simulation becomes reality and the "feeling of representative fades" (Crook, 1990:15), so much so that the world outside the simulation becomes, paradoxically, imaginary for a more detailed explanation of the mechanics of simulations. Simulation is an extremely valuable for second learning. It encourages thinking and creativity, lets students develop and practice new language and behavioral skills in a relatively nonthreatening setting, and can create the motivation and involvement necessary for learning to occur.

This paper will examine this technique in detail. Simulations simulate real life situations, while in role playing the participant is representing and experiencing some character type known in everyday life. Simulations always include an element of role play. Simulation clearly promotes effective interpersonal relations and social transactions among participants. In order for a simulation to occur the participants must accept the duties and responsibilities of their roles and functions and do the 
best they can in the situation in which they find themselves. To fulfill their role responsibilities, students must relate to the others in the simulation, utilizing effective social skills (Kaplan, 1997). By using Simulation Technique, the students would use language by their own action or in team. Smith, et.all (1992: 5) states that following simulation, there is usually a lengthy discussion where students reflect on the simulation and explore their own action and those of others. Furthermore, the students will speak in the class as like as they speak in their real life. Hence this research is discussing about how the Simulation Technique improveme the students' speaking accuracy. Additionally, the teachers who concentrate on accuracy help their students to produce grammatically correct written and spoken English (Sangkala, 2012)

\section{METHOD}

In this research, the researcher would use a Classroom Action Research (CAR) that would be done through cycle with four steps, namely: 1) planing,2)Action, 3)Observation, 4) reflection. Then the population of the research was the second grade year students of SMA Muhammadiyah 7 Makassar. There were two kinds of variable in this research. They were independent variable which in this research was the application of Simulation Technique, and dependent variable which was the improvement of the students' speaking skill in term of speaking accuracy.

To get information about students' improvement in speaking accuracy after teaching learning process through Simulation Technique, the researcher would give the students an oral test after teaching learning process in the end of cycle. Furthermore, in collecting data, the researcher would give an observation test before giving action and at last would give evaluation as the reflection. The data result would collect from the result of an oral test as an instrument of the research to know students' speaking ability in observation and reflection. The procedure as follows: The students would be called out in pair and the researcher would test them by giving situations relating to the material. Furthermore, the researcher would ask the students to make a simulation based on the situation that they would get and the 
researcher would use Tape Record to record the students' conversation in that simulation.

To calculate the mean score, the following formula was applied:

$$
\overline{\mathrm{x}}=\frac{\sum \mathrm{x}}{\mathbf{N}}
$$

Where: $\quad X=$ Mean score

$$
\begin{aligned}
& \sum \mathrm{x}=\text { The sum of all score } \\
& N=\text { The number of students }
\end{aligned}
$$

1. To convert the score (Heaton score) to the students' score, the formula which used as follows:

$$
\text { Score }=\frac{X}{N} \quad X 10
$$

Notation : $\quad \mathrm{X}=$ Score of the Students

$$
\begin{aligned}
& N=\text { Score Maximum } \\
& 10=\text { Standard score }
\end{aligned}
$$

2. To know the percentage of the students' improvement by applying the following formula:

$$
P=\frac{X 2-X 1}{X 1} \times 100
$$

$$
\begin{array}{cl}
\text { Where } & : \\
\text { P } & : \text { Percentage } \\
\text { X1 } & : 1^{\text {st }} \text { Cycle } \\
\text { X2 } & : 2^{\text {nd }} \text { Cycle }
\end{array}
$$

3. To calculate the percentage of the students' observation result, the formula which used as follows:

$$
\mathrm{P}=\frac{\mathrm{Fq}}{4 \mathrm{xN}} \times 100
$$

Notation: $\quad \mathrm{P}=$ Percentage

$\mathrm{Fq}=$ Frequensi

$\mathrm{N}=$ the number of students 


\section{RESULT}

The use of Simulation Technique in improving the students' speaking accuracy is dealing with pronunciation (PRO), grammar (GRA), and Vocabulary (VOC). In the cycle I the students got low score (5.6) because they were still afraid to speak in front of their friends and they didn't understand well about the steps of Simulation Technique, beside that they couldn't explore their creativity well in making their own simulation. It was caused of the researcher recognizing to the students was still low and the researcher still efforted to look for the students' weakness in speaking accuracy which deals with pronunciation, grammar, and vocabulary. Furthermore, the students still didn't accostume in Simulation Technique.

In the cycle II the students' accuracy score in speaking finally improve became 7.3 because in this cycle the researcher could recognize the students' well, then the researcher also found the weakness of the students' speaking skill which deals with pronunciation, grammar, and vocabulary, and gave the suitable action for their weakness. Furthermore, the students were accostumed in teaching and learning process through Simulation Technique. The improvement of the students' speaking accuracy dealing with pronunciation, grammar, and vocabulary can be seen clearly in the following table:

Table 1. The Improvement of the Students' Speaking Accuracy

\begin{tabular}{|c|c|c|c|}
\hline \multirow{2}{*}{ No } & \multirow{2}{*}{ Indicators } & \multicolumn{2}{|c|}{ The Student' Score } \\
\cline { 3 - 4 } & & Cycle I & Cycle II \\
\hline 1. & Pronunciation & 5.3 & 6.5 \\
\hline 2. & Grammar & 5.4 & 7.1 \\
\hline 3. & Vocabulary & 5.6 & 7.5 \\
\hline 4. & $\bar{X}$ & 5.4 & 7 \\
\hline
\end{tabular}

The table above shows the improvement of the students' speaking accuracy which deals with pronunciation, grammar, and vocabulary. In cycle I is 5.4 and in 
the cycle II increase to the 7. It has achieved the standard score of SMA. The result observation of the students in teaching and learning process toward the use of Simulation Technique in improving the students' speaking skill at the second grade students of SMA Muhammadiyah 7 Makassar in class XI IPA which was conducted in 2 cycles during 8 meetings is taken by the observer through observation sheet. It can be seen clearly through the following table:

Table 2. The Observation Result of the Students in Learning Process.

\begin{tabular}{|c|c|c|c|c|c|}
\hline \multirow{2}{*}{ Cycle } & \multicolumn{4}{|c|}{ Meetings } & $\begin{array}{c}\text { Average } \\
\text { score }\end{array}$ \\
\cline { 2 - 6 } & $1^{\text {st }}$ & $2^{\text {nd }}$ & $3^{\text {rd }}$ & $4^{\text {th }}$ & \\
\hline I & $56.8 \%$ & $59 \%$ & $65.9 \%$ & $70.4 \%$ & $\mathbf{6 3 \%}$ \\
\hline II & $78.4 \%$ & $81.8 \%$ & $82.9 \%$ & $87.5 \%$ & $\mathbf{8 2 . 7 \%}$ \\
\hline
\end{tabular}

The table above shows that the students' participation in cycle I was lower than the students' participation in cycle II. It is because in cycle I, Simulation Technique method was unfamiliar with them. They were still did not know that technique's steps and purposes. The researcher also limited the students chance to speak intensively. Therefore, the students were not interested in learning because they didn't enjoy the material. As result they were less active to participate in learning and teaching process. But in cycle II the researcher tried to give clearer instruction to students about Simulation Technique. As result, the students became accustom with it. They got many chance to speak intensively, so during this cycle they became more active than previous cycle.

\section{DISCUSSION}

The findings has showed the improvement of the students' speaking skill through Simulation Technique, it was 5.6 in the cycle I became 7.3 in cycle II. It could be happened because of the effort from the researcher in this classroom action research. 
As like as the explanation before, in the cycle I the students' speaking skill were low because in the first cycle the students were still lazy to speak in front of the class and they didn't have much interest in the Simulation Technique. Some students sometimes didn't want to join in the Simulation of their group without the researcher forcing. It was because in the first, the Simulation Technique' steps was confusing for them and they still didn't recognize this technique well. But in the cycle II the students felt very fun and enjoy in teaching and learning process through Simulation Technique. It was because the researcher gave deep understanding of the Simulation Technique to the students and gave more chance to the students to perform their Simulation as many as possible.

Beside that in the cycle II the students' speaking skill improved because in the cycle II the researcher improved the Simulation Technique became fun and enjoy through the researcher Simulation performance and gave the theme for each meeting.

In the first meeting in cycle I, the teacher checked the students name and introduce the Simulation Technique. Then the teacher explained the material ( Expressing pleasure, pain, and relief). After that, the teacher divided the students into six groups. The teacher distributed a situation card which was consisted of the explained material and asked the students to discuss and made their groups Simulation based on the situation in the card. Then, every group performed their Simulation. And then the teacher lead the students to discuss their mistake in their Simulation.

In the second meeting, the teacher checked the students name and review the last material. Then the teacher explained the material (Spoken Report Text). After that, the teacher divided the students into six groups. The teacher distributed a situation card which was consisted of the explained material and asked the students to discuss and made their groups Simulation based on the situation in the card. Then, every group performed their Simulation. And then the teacher lead the students to discuss their mistake in their Simulation. 
In this meeting, the teacher checked the students name and review the last material. Then the teacher explained the material (Expressing Advice ). After that, the teacher divided the students into six groups. The teacher distributed a situation card which was consisted of the explained material and asked the students to discuss and made their groups Simulation based on the situation in the card. Then, every group performed their Simulation. And then the teacher lead the students to discuss their mistake in their Simulation.

In the the last meeting of cycle I, the teacher checked the students name and review the last material. Then the teacher explained the material (Expressing Warning). After that, the teacher divided the students into six groups. The teacher distributed a situation card which was consisted of the explained material and asked the students to discuss and made their groups Simulation based on the situation in the card. Then, every group performed their Simulation. And then the teacher lead the students to discuss their mistake in their Simulation.

In the fifth meeting in the cycle II, the teacher checked the students name. Then the teacher explained the material (Expressing Granting Requesting). After that, the teacher gave eample of the simulation through performance in front of the students. The teacher divided the students into pairs. The teacher distributed a situation card (Theme: School) which was consisted of the explained material and asked the students to discuss and made their pair's Simulation based on the situation in the card. Then, every pair performed their Simulation. And then the teacher lead the students to discuss their mistake in their Simulation.

In the sixth meeting in the cycle II, the teacher checked the students name and review the last material. Then the teacher explained the next material (Story Telling). After that, the teacher gave eample of the simulation through performance in front of the students. The teacher divided the students into pairs. The teacher distributed a situation card (Theme: Animals myth) which was consisted of the explained material and asked the students to discuss and made their pair's Simulation based on the situation in the card. Then, every pair performed their 
Simulation. And then the teacher lead the students to discuss their mistake in their Simulation.

In this meeting in the cycle II, the teacher checked the students name and review the last material. Then the teacher explained the next material (Expressing Asking and Giving Opinion). After that, the teacher gave eample of the simulation through performance in front of the students. The teacher divided the students into pairs. The teacher distributed a situation card (Theme: Music) which was consisted of the explained material and asked the students to discuss and made their pair's Simulation based on the situation in the card. Then, every pair performed their Simulation. And then the teacher lead the students to discuss their mistake in their Simulation.

In the last meeting in the cycle II, the teacher checked the students name and review the last material. Then the teacher explained the next material (Expressing Satisfied and Dissatisfied). After that, the teacher gave eample of the simulation through performance in front of the students. The teacher divided the students into pairs. The teacher distributed a situation card (Theme: Holiday) which was consisted of the explained material and asked the students to discuss and made their pair's Simulation based on the situation in the card. Then, every pair performed their Simulation. And then the teacher lead the students to discuss their mistake in their Simulation.

After exceeded the process above, the data analysis for the students' speaking skill in terms accuracy and fluency improve significantly. It's indicated from the result of the D-test which was only 3.5, it's classified as very poor, in the cycle I the students' score was 5.6 and it's still classified as fair, and in the cycle II the students' score in speaking skill improved became 7.3 which is classified as good and could achieve the standard score of SMA.

\section{CONCLUSION}

Based on the research findings and discussions in the previous chapter, the following conclusions are presented: a. teaching and learning through Simulation Technique is able to improve the students' speaking accuracy at the second year 
students' of SMA MUHAMMADIYAH 7 Makassar. It is proved by the students' achievement in cycle II is higher than cycle I and D-Test where in D-Test the students' mean score achievement in speaking accuracy is 3.4, but after evaluation in cycle I the students' speaking accuracy becomes 5.4 and cycle II 7, b. teaching and learning through Simulation Technique is able to improve the students' speaking fluency at the second year student of SMA MUHAMMADIYAH 7 Makassar. It is proved by the students' achievement in cycle II is higher than cycle I and D-Test where in D-Test the students' mean score achievement in speaking fluency is 3.6, but after evaluation in cycle I the students' speaking fluency becomes 5.9 and cycle II 7.6, c, teaching and learning through Simulation Technique is able to make the students more active in learning process, especially in speaking activities because Simulation Technique is one of the fun ways in learning English especially speaking.

\section{REFERENCES}

Crook D. (1990). Simulation, gaming, and language learning (pp. 151-158). New York: Newbury House.

Dornyei, Z. and Mhurphey, T. (2003) Group Dynamics in the Language Classroom. Cambridge: Cambridge University Press.

Gay, R.L., Mills and Airasian, P. 2006. Educational Research Competencies for Analysis and Aplication ( $8^{\text {th }}$ edition). New Jersey: Meril Prentice Hall

Heaton, J. B. 1988. Writing English Language Test. New York: Longman Inc.

Kaplan, M.A.1997. Article. Role Playing/Simulation.http://itslj/simulation/tompkins-roleplaying.org

Moleong, J. L. 2006. Metodologi Penelitian Kualitatif. Bandung: Remaja Rosdakarya

Richard, Jack C and Renandya. 2002. Methodology in Language Teaching. New York: Cambridge University. 
Riwindiasih, Susi. 2009. Collaborative Learning Model in Teaching Speaking Using Role Play Based on the School Level Based Curriculum to the First Tear Students of SMA N 1 Sragen in 2007/2008 Academic Year. Thesis FKIP Muhammadiyah University of Surakarta.

Sangkala, I. (2012, May). The Implementation of "ARIAS" Strategy to Increase Students Speaking Skill at SMA Negeri 1 Bungoro. Exposure, 1(1), 59-76. doi:http://dx.doi.org/10.26618/ejpbi.v1i1

Smith, Leigh, Barbara and MacGregor, J. 1992. What Is Collaborative Learning? Pennsylvania State University.

Widdowson, H.G. 1978. Teaching language as communication. Oxford. University press. 